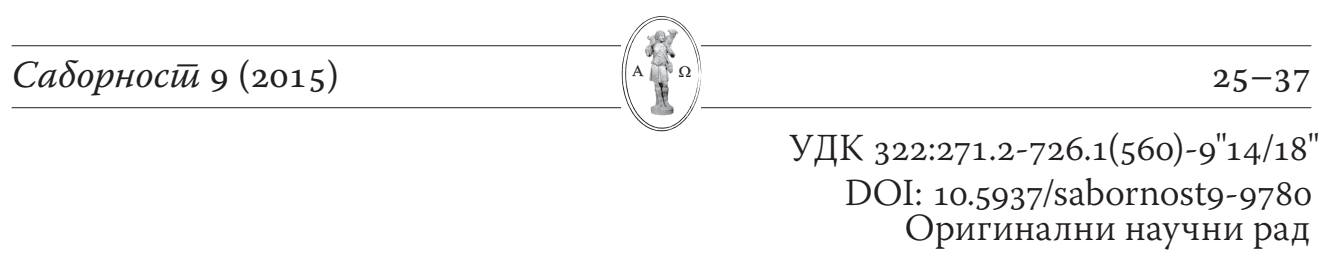

\title{
Јов Геча
}

Православни институт Васељенске патријаршије у Шамбезију, Женева

\section{Примат Васељенског патријарха у Отоманској империји}

\begin{abstract}
: Падом Византије 29. маја 1453. године, појавиће се нов модел односа између Цркве и државе у старој Римској империји на Истоку. Ово ће имати за последицу да систем пентархије, развијен у првом миленијуму, добије сасвим други облик на хришћанском Истоку, пошто овај буде потчињен отоманском јарму. Нови модел односа Цркве и нове Империје врло брзо ће се одразити на односе међу источним патријарсима, али и на место и улогу примата васељенског патријарха.
\end{abstract}

Key words: примат, васељенски патријарх, модел Цркве, Отоманска империја, национализам.

\section{Нови модел}

$\prod^{2}$ адом Византије 29. маја 1453. године, појавиће се нов модел односа између Цркве и државе у старој Римској империји на Истоку. Ово ће имати за последицу да систем пентархије, развијен у првом миленијуму, добије сасвим други облик на хришћанском Истоку, пошто овај буде потчињен отоманском јарму.

Султан Мухамед II, који је имао не само грчку крв у својим венама него и велико дивљење према грчкој култури, покушавао је да буде прихваћен за наследника римских императора и да игра њихову улогу онолико колико му је то дозвољавала његова религија. Из тог разлога, био је свестан да мора придобити Грке ради престижа своје нове империје, и то је разлог што се трудио да одржава добре односе са хришћанским народом којег је управо освојио. Испоставило се чак да се Мухамед II интересовао за хришћанство и, с тим у вези, велики византијски интелектуалац и будући патријарх цариградски Генадије Схоларис је написао за њега кратко изложење православне вере које је требало да буде преведено на турски ${ }^{\mathbf{1}}$.

Да би организовао хришћане у Отоманској империји, Мухамед II изабрао је систем који су Отомани већ користили за друге мањине: систем

1 Runciman, 1985, стр. 183. 
милета (celui des millets). То је значило да је свака од ових националних мањина могла имати своју самоуправу са својим сопственим законима и обичајима. Верски поглавар сваког милета (millet) био је задужен да надгледа администрацију, уредно и у складу са отоманском влашћу. Тако се васељенски патријарх нашао на челу хришћанског милета (Rum Milleti) и постао етнарх: поглавар народа православних хришћана са титулом „millet bashi“. Може се рећи да је тако васељенском патријарху у Отоманској империји припала улога коју је некад имао хришћански император у Источном римском царству ${ }^{2}$.

Дан након заузимања Цариграда, патријаршка столица је упражњена: уочи заузимања Цариграда, Григорије Мамас, последњи патријарх Источног римског Царства, абдицирао је и избегао у Италију 1451. Требало је дакле пронаћи новог патријарха. Мухамед II озбиљно је размотрио ово питање из управо наведених разлога и лично се определио за личност Генадија (по крштењу Григорија) Схолариса. Било је извесно да овај, с обзиром да је као наследник Марка Евгеникоса био вођа антиунијонистичког и антизападног покрета непосредно по Флорентинском сабору, неће правити никакве мутне радње са Римом, нити представљати на тај начин било какву опасност за стабилност Отоманске империје. Поставши роб једног богатог Турчина после пада Византијске империје, Схоларис је ослобођен по нарећењу султана и позван пред њега: прихватио је предлоге Мухамеда II и заједно са њим дефинисао будуће односе између Православне Цркве и нове „иноверне“ државе.

Генадије је тако изабран у јануару 1454. године на сабору састављеном од епископа које је султан успео да окупи. Примио је из руку Мухамеда II инсигније свог новог достојанства и затим био устоличен у цркви Дванаесторице Апостола, пошто је Света Софија претходно била претворена у џамију

Према Францезу, сувременом историчару, Мухамед II је изгледа дао Генадију Схоларису својеручно потписани ферман и доделио васељенском патријарху личну неповредивост (une inviolabilité personnelle), ослобођење од пореза, слободу кретања, јемство против ма каквог свргавања (déposition) као и право преношења ових привилегија на своје наследнике. Међутим, јемство против ма каквог свргавања би довело до кршења права у надлежности Синода, па је, према другим познијим историчарима, то био разлог што је Мухамед II изгледа дао Схоларису документ по ком овлашћује Цркву да чува своје законе о браку и погребу, а хришћаниме да буду слободни да славе Васкрс у трајању од три дана ${ }^{4}$. Међутим, никакав

2 Kartašev, 1936, стр. 13.

3 Papadopoulos, 1952, стр. 2; Runciman, 1985, стр. 168-169.

4 Bekker, 1938, стр. 304-307; Runciman, 1985, стр. 170; Papadopoulos, 1924, Стр. 1-39; Laurent, 1929, стр. 398-406. 
ферман није сачуван; већ 1520. године, патријарх Теолепт I изјављује да је овај документ уништен приликом неког пожара 5 .

Из овога усменог или писменог договора између султана и новог патријарха произишао је један нови модел односа између Православне цркве и Отоманске државе. Патријарх и његов синод су имали, уз свој доктринарни ауторитет, и пуну власт над православним хришћанима на Истоку. Кривични поступци који се тичу клирика строго покренути на црквеном суду који је, осим тога разматрао и све предмете који се односе на лаике а имају религијску конотацију: венчање, развод, чување деце, тестаменти и наследства. Осим тога, патријарх, самим тим што је био и етнарх, морао је да пази да православни хришћани плаћају дажбине султану и имао обавезу да кажњава непокорне 6 . Пошто је све више и више имао да решава предмете из области грађанског права а понекад и да сарађује са турским судовима, васељенски патријарх је морао да тражи помоћ адвоката и правника лаика7. Поменути лаици наслеђивали су функције у крилу патријарашког двора које су некад припадале клирицима. Ово се може објаснити потребом да помажу патријарху у његовој улози етнарха у задацима који су у давнини припадали императору и његовој курији ${ }^{8}$

\section{Судбина источних патријараха у Отоманској империји}

Нови модел односа Цркве и нове Империје врло брзо ће се одразити на односе међу источним патријарсима. Уласком територија Александријске, Антиохијске и Јерусалимске патријаршије у састав Отоманске империје 1517. године, Велика порта припојила је њихове вернике милету православних хришћана (Rum Milleti) који су се налазили под ауторитетом етнарха (васељенског патријарха) желећи да сви послови буду централизовани у Цариграду. Премда су теоријски, гледано из угла православне еклисиологије, ове патријаршије, задржале своје аутономије и своја црквена права, оне су ce de facto нашле потчињене ауторитету васељенског патријарха сходно његовом својству етнарха. Тако је Цариградска патријаршија, више него икад, постала велики центар црквеног живота од кога су зависиле све остале источне патријаршије ретски сачувала своју аутокефалију, она је чињенично зависила од Цариграда још од венецијанске окупације острва.

Сви преговори ових патријаршија са Великом портом морали су се обавезно одвијати посредством њиховог брата из Цариграда. Тако, не

\footnotetext{
5 Runciman, 1985, стр. 189.

6 Runciman, 1985, стр. 171. Papadopoulos, 1924, стр. 27-39.

7 Runciman, 1985, стр. 173-176; Papadopoulos, 1924, стр. 39-41.

8 Runciman, 1985, стр. 176.

9 Kartašev, 1936, стр. 14. Видети исто тако: Sokolov, 1904, стр. 13-15.
} 
само кад је нека епархија била упражњена, већ и када је катедра неке од ових патријаршија бивала упражњена, на васељенском патријарху је било да затражи дозволу од султана да је попуни. У ствари, у Отоманској империји, за сваки избор епископа, било је неопходно добити документ звани barat којим је кандидат постављан на одређену катедру, а у надлежности васељенског патријарха било је да то затражи дозволу од Велике порте. Будући да султан није био ни мало заинтересован да бира кандидата, осим у погледу својих финансијских интереса, васељенском патријарху (и његовој окружењу) било је лако да предложи кандидата кога жели ${ }^{10}$.

У економском погледу, источни патријарси су били релативно сиромашни. Александријска патријаршија је преживљавала захваљујући финансирању грчких трговаца из Александрије. Треба рећи да је ова патријаршија била већински састављена од Грка настањених у Египту пошто је локално становништво генерално припадало пре-халкидонској Коптској Цркви. Александријски патријарси су највећи део времена обитавали у Цариграду, а њихова катедра понекад чак није била ни попуњавана. Патријаршијом је обично администрирао архимандрит који је боравио у Каиру. У XIX веку, већина изабраних патријараха за ову катедру су били кандидати предложени од стране Фанариота ${ }^{11}$.

Антиохијска патријаршија, чија је катедра још од времена Крсташких ратова била пресељена у Дамаск, била је најсиромашнија, и преживљавала је захваљујући донацијама сиријских православних трговаца. Они су били углавном локални Арапи, иако је клерикална елита била већински грчка. Дуго времена Антиохијска патријаршија је наставила да сама локално бира свога патријарха, али се већ у XIX веку избор обављао у Цариграду. На пример, 1850. године, клир Александријске патријаршије пише васељенском патријарху „молећи Синод Цариградске патријаршије“ да им именује патријарха из клира престонице ${ }^{12}$.

Иста ситуација била је и у Јерусалимској патријаршији која је одувек била најбогатија, захваљујући прилозима бројних ходочасника који су овде и даље притицали, а нарочито захваљујући финансијској подршци Руса као и молдавских и влашких кнежева. Пошто су се ови последњи добровољно потчинили султану, они су могли сачувати одређену аутономију и заштити тако своје богатство ${ }^{13}$. Уосталом, патријарси су одлазили у ове крајеве да прикупљају прилоге како би на тај начин задовољили потребе својих патријаршија. Ипак, припајање Палестине Отоманској империји 1517. године ставило је тачку на локалне изборе Јерусалимског патријарха из арапског клира. Јерусалимски патријарси бирани су у Цариграду где су,

\footnotetext{
10 Runciman, 1985, стр. 176-178; Papadopoulos, 1924, стр. 86-89.

11 Kartašev, 1936, стр. 14.

12 Lebedev, 1904, стр. 773-781.

13 Runciman, 1985, стр. 177, 195.
} 
шта више, и обитавали (у свом метоху), тако да су верни Јерусалима, током два века, имали врло мало прилике да виде сопственог епископа на лицу места. У XIX веку, цариградски патријарх је у више наврата покушао да укине аутокефалију Јерусалимске патријаршије: ово је био случај Константина I (1830-1834) и Германа IV (1845). Избор јерусалимског патријарха од стране његовог синода обновљен је тек 1845. године и то захваљујући посредовању руске дипломатије ${ }^{\mathbf{1 4}}$.

Судбина словенских Цркава је била још комплекснија. Анексијом Бугарске и Србије од стране Отоманске империје, њихове патријаршије су биле укинуте и претворене, свака за себе, у аутономне митрополије Трнова (или Охрида) и Пећи, обе зависне од Цариградске патријаршије. Ове две Цркве су ипак сачувале своје литургије на словенском језику и бориле се против свих покушаја јелинизације од стране Фанариота у XIX веку. Од 1557. до 1755. године, Пећка патријаршија је била привремено успостављена. Међутим, због притиском Фанариота, аутономне митрополије Пећи и Охрида биле су једноставно укинуте од 1766-1767. године, а Српска и Бугарска Црква стављене под јурисдикцију егзарха васељенског патријарха који је чинио све да у овим крајевима наметне грчке епископе, што је допринело да се код ових народа створи мржња према грчком народу. Црква у Црној Гори - брдоликој области Балкана коју Отомани никада нису успели да освоје - сачувала је ипак своју аутономију у односу на Цариград ${ }^{15}$.

Молдавска и Влашка митрополија, некада у саставу Српске Цркве, нашле су се исто тако у саставу Васељенске патријаршије. Елита ових крајева ипак је била више окренута ка Грцима него ка Словенима, и потпомагала је финансијски Васељенску патријаршију, тако да су дунавски кнежеви успевали да поставе своје кандидате на патријарашку столицу ${ }^{\mathbf{1 6}}$. Штавише, склопљено је више бракова између кнежевских породица ових регија са Фанириотима из Истанбула, често у нади да ће ове цариградске породице одбранити њихове интересе пред султаном. Доласком Фанариота у ове кнежевине, Црква је била јелинизована: елита клира често је била грчка или је имала грчко образовање, а овде су биле основане и грчке школе и семинарије $\mathbf{1 7}^{\mathbf{7}}$.

Грузијска Црква, која ће сачувати своју аутономију све до свога припајања Руској Цркви, иако није била под отоманским јармом захваљујући чињеници што је грузијски цар био независни монарх, ипак је зависила од Цариграда ${ }^{\mathbf{1 8}}$.

\footnotetext{
14 Kartašev, 1936, стр. 17; Lebedev, 1904, стр. 781-786.

15 Runciman, 1985, стр. 379-38о. Видети исто тако: Hadrovice, 1947.

16 Runciman, 1985, стр. 195; Iorga, 1935, стр. 84-86.

17 Runciman, 1985, стр. 365-370; Iorga, 1935, стр. 126-154.

18 Runciman, 1985, стр. 195-196.
} 


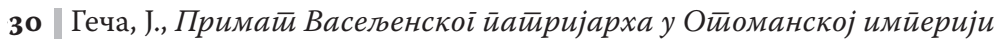

Што се тиче Руске Цркве, она је с једне стране била разочарана у Грке због потписивања Флорентинске уније од стране митрополита кијевског Исидора, а с друге стране због пада Византије. Први разлог је подстакао руски народ да протера Исидора са његове столице. Други разлог је допринео, с обзиром да више није било православног императора у Цариграду и да је патријарх био потчињен султану, да се развије теорија „Москве као трећег Рима“. У таквим околностима Руска Црква је сама, без пристанка Цариграда, приступила избору митрополита Јоне 1448. године, прогласивши се аутокефалном тим чином. Тек је 1589. године, у време проласка патријарха Јеремије II кроз Русију ради прикупљања прилога, Цариград признао, уз сагласност тројице осталих патријарха који су му на неки начин били потчињени, аутокефалију Руске Цркве, дајући јој статус патријаршије, и уписујући је у диптихе одмах иза Јерусалимске. Можемо рећи заједно са S. Runciman, да је идеја Јеремије II била „вешта и интелигентна“, да призна Москви место „трећега Рима“, на политичком плану, с обзиром на чињеницу да је Цариград био под отоманским јармом, притом ипак потчинивши Руску Цркву примату цариградскога патријарха, тако што ју је унео на пето место ове нове источне пентаршије. Треба запазити међутим да је, упркос овим историјским околностима, Руска Црква наставила да гледа на Васељенску патријаршију са поштовањем ${ }^{\mathbf{1 9}}$. Што се тиче укидања патријаршије од стране Петра Великога 1721. године, Васељенска патријаршија је на то гледала са наклоношћу јер је на неки начин Руска Црква враћена под духовни ауторитет Васељенске патријаршије ${ }^{20}$.

Осим тога, не треба заборавити да је један део старе кијевске митрополије, налазећи се тада у Пољско-Литванској држави, што одговара данашњој Украјини, наставио да зависи од Цариградске патријаршије, и то све до 1686. године. Штавише, између 1620. и 1679. године, сви кијевски митрополити су били егзарси васељенскога патријарха. Тек је након уједињења Мале са Великом Русијом које се догодило 1654. године, као и под притиском Отомана, васељенски патријарх Дионисије IV прихватио, у замену за једну пристојну суму новца, да придружи овај део старе кијевске митрополије Руској Цркви маја 1686.

\section{„Велика грчка идеја“ и национализми XIX века}

Византијска империја је била васељенска у смислу да је била састављена од различитих нација које су живеле заједно. Исто тако, пентархијски систем је био развијен у току првог миленијума на територијалној основи, а не на националној. Једног дана, питали су Генадија Схолариса које је националности. На ово питање одговорио је: Не сматрам се Грком иако сам Грк по раси, нити Византијцем премда сам рођен у Византији, него

\footnotetext{
19 Runciman, 1985, стр. 330-332.

2 Runciman, 1985 , стр. 381.
} 
радије хришћанином, што ће рећи православцем. Како би сачувала своју моћ у Отоманској империји, Црква и православни милет (Rum Milleti) су морали чувати своје својство „васељенски“ како не би постали само помесна Црква или један грчки милет ${ }^{21}$.

Нажалост, овај православни милет (Rum Milleti), наследник Римске империје на Истоку, постао је својим духом мало по мало грчки милет, иако то није било по установљењу. Улога васељенског патријарха као етнарха састојала се у служењу јелинизму: њега потчињени Грци нису сматрали оцем хришћанских народа, већ оцем велике грчке нације. Али у тим условима, зар је етнарх Rum Milleti-а могао остати етнарх Арапа и Словена? Да ли је могуће помирити јелинизам и васељенски карактер?

Ова несрећна метаморфоза Васељенске патријаршије, нарочито она у XIX веку, настала је - видели смо то из горе наведених неколико примера - под утицајем политике Фанариота. Ови су потицали из богатих и амбициозних породица које су се сматрале „архонтима“ грчког народа и које су настојале да контролишу васељенског патријарха који је, као етнарх, представљао у њиховим очима највиши ауторитет међу Грцима. Они су почели да граде своје куће у околини патријаршијске зграде у кварту званом Фанар у Истамбулу где је била премештена столица Васељенске патријаршије око 16оо. године. Мало по мало, уводили су своје синове у патријаршијски двор, и тако, од XVII века ове породице заузимају контролу над Црквом. Будући богате, ठиле су у могућности да исплате црквене дугове и да праве сплетке код Велике порте ${ }^{22}$. На тај начин Фанариоти су чак успели да преузму контролу у XIX веку над Црквама Александрије, Антиохије, Јерусалима, Молдавије и Влашке.

Фанариоти су ти који су сковали „велику грчку идеју“ са циљем да обнове Византију преко јелинизма. Грци су претендовали да буду изабрани народ. Сматрајући се „Ромејима“, уложили су све своје напоре како би обновили један Нови Рим који би био грчки, који би био центар грчке културе и који би окупљао свеукупан православни свет. Али зар је било могуће у овој мешавини неовизантизма и грчког национализма, ускладити јелинизам и икуменизам, службу свеукупног православног света и служ$\delta у$ грчке нације? ${ }^{23}$ Да ли је улога која је припала васељенском патријарху у Отоманској империји била да представља етнарха хришћанских народа или етнарха велике грчке нације? Нажалост, резултат фанариотске политике био је да преобрази Православну Цркву у Отоманској империји у једну Грчку Цркву, па је Цариградска патријаршија постала више грчка него васељенска.

\footnotetext{
21 Runciman, 1985, стр. 379.

22 Runciman, 1985, стр. 360-362; Iorga, 1935, стр. 90-91, 113-125.

23 Runciman, 1985, стр. 378. Voyatzidis, 1953, стр. 279-285.
} 


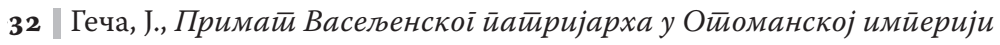

Овај пораст грчког национализма уједињеног са отоманском доминацијом допринео је рађању различитих националистичких покрета на Балкану, изазивајући међу овим Словенима спонтану реакцију против јелинизма. Непријатељство између Грка и Словена у то време може се запазити чак и између грчких и словенских монаха на Светој Гори ${ }^{24}$. Да ли је могао васељенски патријарх и даље остати лидер православне васељене или пак првак филетизма насупрот балканским национализмима?

Адамантиос Караис постао је вођа националистичког грчког покрета који је довео до независности Грчке 1830. године, што је повукло за собом успостављање Краљевине Грчке и аутокефалију њене Цркве ${ }^{25}$. По узору на Грчку, различити православни народи Балкана, како су се ослобађали отоманског ропства једни за другима, тако су желели да успоставе сопствену националну Цркву након оснивања своје независне националне државе. На тај начин биће самопроглашене аутокефалије Румунске (1865) и Бугарске Цркве (1870). Касније ће тек Васељенска патријаршија овим Црквама дати канонски и синодално признати статус аутокефалних Цркава: Грчкој Цркви 1850. године, Српској Цркви 1879. године, Румунској Цркви 1885. године, и Бугарској Цркви $1945^{26}$.

Тако ће нова геополитичка ситуација православног света са краја XIX века - која је делимично резултат потраге за ослобођењем од отоманског јарма а делимично последица пораста национализама - креирати нови црквени хоризонт путем проглашења различитих аутокефалија и успоставити међу различитим аутокефалним Црквама односе чије ћемо извесне тензије моћи запазити крајем XX века.

\section{Примат цариградског патријарха у Отоманској империји}

Може ли се говорити о primus inter pares Цариградске патријаршије у околностима које смо управо поменули, у којима је патријарх уживао квази-супрематију над свим другим патријаршијама? На један одређени начин, А. Карташев је имао права тврдећи да је у тој епохи „Васељенска патријаршија" апсорбовала читаву Цркву Истока ${ }^{27}$. Можемо видети очигледан пример ове централизације у време патријарховања Самуила (1763-1774) који је укинуо Пећку патријаршију 1766, аутономију Охрида 1768. и сам приступио избору и устоличењу патријараха Антиохије и Александрије $1766^{28}$.

\footnotetext{
24 Runciman, 1985, стр. 391; Видети исто тако: Fennell, 2001.

25 Runciman, 1985, стр. 392-406.

26 О овом питању видети: Papathomas, 2001, стр. 75-92; Papathomas, 2003, стр. 149-170; Getcha, 2011, стр. 93-104.

27 Kartašev, 1936, стр. 13.

${ }^{28}$ Kartašev, 1936, стр. 14.
} 
Ова нова ситуација изазвала је уосталом један посебан и јединствен феномен: прелазак патријараха с једне столице на другу. Најпознатији пример поменутога јесте патријарх Кирило Лукарис који је прво заузео Антиохијску столицу 16о1. године пре него што је био изабран за васељенског патријарха $1612^{29}$. Ипак, ово премештање није било увек и неопходно унапређење ка столици Цариграда. Један други добар пример је Софроније IV који је био изабран за александријског патријарха (1870-1899) након што је пре тога био васељенски патријарх ${ }^{30}$.

Упркос овој новој и без преседана ситуацији, не треба потценити чињеницу да је дух синодалности био занемарен од стране васељенског патријарха пошто је једном преузео улогу етнарха. Довољно је, да бисмо се у ово уверили, да поменемо шест примера.

1. Први је повезан са стварањем Московске патријаршије 1589. Руски историчар и канонист В. Ципин нам је привукао пажњу у својој књизи Канонско йраво на чињеницу да је васељенски патријарх Јеремија II, пошто је дао статус патријаршије Руској Цркви 1589. године током свог путовања ради прикупљања прилога у Русији, сазвао у мају 1590. године сабор у Цариграду како би потврдио статус патријарха епископу Москве и његово место у диптисима. На овоме сабору су учествовали патријарси Јоаким Антиохијски и Софроније Јерусалимски (Александријска столица је била тада упражњена) ${ }^{31}$. Руска Православна Црква се у данашње време позива врло често на ову чињеницу како би показала да установљење аутокефалије не може бити повластица Васељенске патријаршије, него захтева свеправославни сабор.

2. Сабор у Јашију 1642. године може нам служити као други пример. Овај сабор био је сазван како би се одлучило о Исйовеgаньу вере митрополита Петра Могиле (1597-1646). Иако ниједан од источних патријарха није био присутан, сабор се одвијао под председавањем молдавског кнеза са учешћем представника Цариградске, Александријске, Антиохијске, Јерусалимске и Московске Патријаршије као и Кијевске Цркве. Иако се он никада није сматрао васељенским сабором, његове одлуке су ипак одобрене од Цариградског Синода, а ове од осталих патријаршија ${ }^{32}$. Потреба да се сазове сабор у Јашију ради изјашњавања о православности овога Исйовеgања вере заиста показује да је ово питање морало бити решавано синодално, а не само од стране васељенског патријарха и његовог синода.

3. Један други пример који предивно илустурује нарочиту улогу васељенскога патријарха и принцип синодалности током овога периода,

\footnotetext{
29 Runciman, 1985, стр. 259-288.

3о Sokolov, 1901, стр. 224-226.

31 Cypin, 1994, део III, секција 4, 3.

32 Runciman, 1985, стр. 342. За одлуке, уп. Mansi, стр. 202.
} 
јесте суђење руском патријарху Никону (1605-1681) из 1666. због спорења овога последњег са царем Алексијем по питању односа између Цркве и државе, пошто је Никон желео да потпуно потчини државу Цркви и да се меша у секуларне послове. То је за последицу имало повлачење Никона са његове функције и [решавање] питања смене патријарха у Руској Цркви која је уживала статус патријаршије још од 1589. Већ 1662. године, архимандрит Игњатије из манастира Полоск је сматрао да се не може решавати овај конфликт без обраћања васељенском патријархуз3. Због тога је цар Алексије сазвао сабор 1666. године на који је позвао источне патријархе. Само су патријарси Пајсије Александријски и Макарије Антиохијски узели на њему личнога учешћа. Ово је навело патријарха Никона да их приупита да ли су овлашћени да му суде ठез сагласности васељенског и јерусалимског патријарха, сматрајући између осталог да је ठио „устоличен на патријарашки трон од стране цариградског патријарха“"34. Ови му одговорише да имају писмену сагласност цариградског и јерусалимског патријарха показујући му два примерка повеље потписане од стране четири источна патријарха и других епископа. Тако је Никон на крају био свргнут и протеран.

4. Можемо исто тако поменути шест локалних сабора одржаних између 1638. и 1691. године ради осуде калвинистички усмереног исповедања васељенскога патријарха Кирила Лукариса (1572-1638). Међу овима, важно је запазити да је сабор из 1638. године у Цариграду био под председништвом његовог наследника Кирила II (Контари) који је доведен на патријарашки трон по наређењу султана, уз учешће патријарха александријског Митрофана (Кристопулоса) и патријарха јерусалимскога Теофана ${ }^{35}$. Лукарисово исповедање било је исто тако одбачено тачку по тачку исповедањем јерусалимскога патријарха Доситеја (1641-1707). Доситејево исповедање је усвојено на Јерусалимском сабору (познатом још под именом Витлејемски сабор) из 1672. године којим је он председавао лично, и у току ког је прочитао енциклику састављену сопственим трудом и сапотписану од стране патријарха цариградскога Дионисија IV и његових претходника Партена IV, Климента и Методија III ${ }^{36}$. Ови примери показују да, по питању теолошких питања, а нарочито православне доктрине, тројица осталих источних патријараха нису били слепо потчињени своме брату из Цариграда, већ да су могли, на један синодалан начин, осудити његове евентуалне грешке.

5. Пети пример који можемо поменути јесте фамозна енциклика источних патријараха из 1848. године, написана исте године када је Рим установио латински патријархат у Јерусалиму. Она је била пре свега одговор на

\footnotetext{
33 Kartašev, 1959, стр. 202.

34 Макарије, 1996, стр. 347.

35 Runciman, 1985, стр. 289.

36 Runciman, 1985, стр. 350.
} 
писмо папе Пија IX којим се јасно потврђује да непогрешивост хришћанске догме у Православној Цркви не зависи од хијерархијског реда већ је поверена хришћанском народу у целости. Енциклика је потписана од стране источних патријараха тога доба, Антима VI Цариградског, Јеротеја II Александријског, Методија Антиохијског и Кирила II Јерусалимског, и потврђена од синода Цариградске, Антиохијске и Јерусалимске Цркве те потписана од стране двадесет и девет епископа. Ово нам јасно показује да су источни патријарси имали пуну свест да морају саборно да одговоре римском папи и да одговор само васељенског патријарха није довољан.

6. На крају, можемо додати као шести пример Свеправославни сабор из 1872. Он је одржан у Цариграду у време кад су Бугари намеравали да створе „националну“ Цркву без прецизних географских одредница, која би имала универзалну јурисдикцију над свим Бугарима, подразумевајући и сам Цариград. Овај сабор је осудио етнофилетизам (религиозни национализам) који је цветао у то доба, као што смо управо видели ${ }^{37}$.

\section{Закључак}

На крају овога прегледа улоге васељенског патријарха у периоду Отоманске империје, можемо у закључку истаћи три тезе које нам се чине основним.

1. У новој геополитичкој ситуацији тога времена, васељенски патријарх је наследио од византијског цара да буде, у својству етнарха, обједињавајући елеменат хришћанскога народа.

2. Организација „Rum Milleti“, на челу са васељенским патријархом, утицала је да се у Цариграду централизује хришћански живот Православне Цркве у Отоманској империји. Због тога можемо рећи да је период отоманског ропства увелико допринео максимализовању улоге васељенског патријарха у крилу православног света.

3. Упркос потчињавању источних патријараха и древних аутокефалних Цркава Цариградској патријаршији на јуридичком и цивилном плану у оквиру Rum Milleti, принцип синодалности је, ма колико тешко ослабљен усред геополитичких околности, ипак био поштован на црквеном плану а васељенски патријарх је наставио да делује као primus inter pares.

\section{Са францускої ӣревео Обраg Карановић}

37 Видети текстове у: Maxime, 1975, стр. 378-383. 


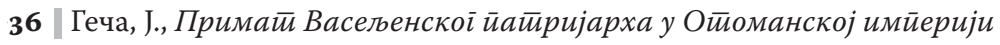

\section{Литература}

Bekker, I. (éd.) (1938). Corpus Scriptorum Historiae Byzantinae. Bonn.

Voyatzidis, J. (1953). La grande idée. Le cinq centième anniversaire de la prise de Constantinople. L'hellénisme contemporain. Athènes.

Getcha, J. (2011). Peut-on justifier la notion 'd'Eglises nationales' du point de vue de l'ecclésiologie orthodoxe?. L'année canonique, 43, 93-104.

Iorga, N. (1935). Byzance après Byzance. Bucarest.

Kartašev, A. (1936). Praktika appelljacionnogo prava Konstantinopol'skix Patriarxov. Varsovie.

Kartašev, A. (1959). Očerki po istorii Russkoj Cerkvi, II. Paris.

Laurent, V. (1929). Les Chrétiens sous les sultans. Echos d'Orient, 28, 398-406.

Lebedev, A. (1904). Istorija Grekovostočnoj Cerkvi pod vlast'ju turok, Saint-Pétersbourg.

Mansi, J. Sacrorum Conciliorum Collectio. vol. XXIV. Florence-Venise.

Макарије, митрополит московски, (1996). Исӣорија Руске цркве, Москва.

Maxime, Métropolite de Sardes (1975). Patriarcat oecuménique dans l'Eglise orthodoxe. Paris.

Papadopoulos, C. G. (1924). Les privilèges du patriarcat oecuménique dans l'Empire ottoman. Paris.

Papadopoulos, T. H. (1952). Studies and Documents relating to the History of the Greek Church and People under Turkish Domination. Bruxelles.

Papathomas, G. (2001). La dialectique entre nation étatique et autocéphalie ecclésiale. L'année canonique, 43, 75-92.

Papathomas, G. (2003). Face au concept de l'Eglise nationale, la réponse canonique orthodoxe: L'Eglise autocéphale. L’Année canonique, 45, 149-170.

Runciman, S. (1985). The Great Church in Captivity A study of the Patriarchate of Constantinople from the Eve of the Turkish Conquest to the Greek War of Independence, Cambridge: Cambridge university press.

Sokolov, I. (1901). Istorija Grečeskix Cerkvej v XIX v. Saint-Pétersbourg.

Sokolov, I. (1904). Konstantinopol'skaja Cerkov'v XIX v. Saint-Pétersbourg.

Fennell, N. (2001). The Russians on Athos. Oxford-Vienne.

Hadrovice, L. (1947). Le peuple serbe et son Eglise sous la domination turque. Paris.

Cypin (Tsypine), V. (1994). Cerkovnoe pravo, Kurs lekcij. Moskva. 


\title{
Job Getcha
}

Orthodox Center of the Ecumenical Patriarch in Chambésy, Geneva

\section{The Primacy of the Ecumenical Patriarch in the Ottoman Empire}

\begin{abstract}
W ${ }^{\text {ith the fall of the Byzantine Empire, May } 29^{\text {th }}}$ 1453, a new model of relaW tionship will appear between the Church and the state within the ancient Roman empire in the East. Consequently, the system of the Pentarchy developed in the first millennium, will receive a different model at the Christian East, because it will be subordinated to the Ottoman yoke. The new model of relationship between the Church and the new Empire will reflect rapidly on the relations among the Eastern Patriarchs, also to the place and role of the primacy of Ecumenical Patriarch.
\end{abstract}

Key words: Primacy, Ecumenical Patriarch, model of Church, Ottoman Empire, nationalism.

Датум пријема чланка: 29. 1. 2015.

Датум прихватања чланка за објављивање: 17. 12. 2015. 